\title{
A Novel Electronic Packaging Method to Replace High-Temperature Sn-Pb Solders
}

\author{
YEE-WEN YEN, ${ }^{1,2}$ HSIEN-MING HSIAO,${ }^{1}$ PEI-SHENG SHAO, ${ }^{1}$ \\ and YEN WEI CHANG ${ }^{1}$
}

\begin{abstract}
1.-Department of Materials Science and Engineering, National Taiwan University of Science and Technology, No. 43, Keelung Road, Section 4, Taipei 106, Taiwan, ROC. 2.-e-mail: ywyen@ mail.ntust.edu.tw
\end{abstract}

The $\mathrm{In} / \mathrm{Ni} / \mathrm{Cu} / \mathrm{Ni} / \mathrm{In}$ multilayer was prepared by an electroplating method to replace high-temperature $\mathrm{Sn}-\mathrm{Pb}$ solders that are conventionally used but are very harmful to the environment. This study shows all the sandwich couples that formed the $(\mathrm{Cu}, \mathrm{Ni})_{6}(\mathrm{Sn}, \mathrm{In})_{5}$ and $\mathrm{Cu}_{2} \mathrm{In}_{3} \mathrm{Sn}$ phases at the interface. When the solder joint was reflowed at $200^{\circ} \mathrm{C}$, a planar layer $(\mathrm{Ni}, \mathrm{Cu})_{3}(\mathrm{Sn}, \mathrm{In})_{4}$ formed near the $\mathrm{Ni}$ layer. When the reflowing temperature was increased to $300^{\circ} \mathrm{C}$, another planar layer $\mathrm{Cu}_{3}(\mathrm{Sn}, \mathrm{In})$ formed near the $\mathrm{Cu}$ substrate. The greater part of the intermetallic compounds in this case were the $(\mathrm{Cu}, \mathrm{Ni})_{6}(\mathrm{Sn}, \mathrm{In})_{5}$ and $\mathrm{Cu}_{3}(\mathrm{Sn}, \mathrm{In})$ phases. The $\mathrm{Cu}_{3}(\mathrm{Sn}, \mathrm{In})$ phase thickness was increased with increasing aging time. The thicker formation of $\mathrm{Cu}_{3}(\mathrm{Sn}, \mathrm{In})$ phase improved the solder-joint strength. The samples reflowed at $300^{\circ} \mathrm{C}$ exhibited the best mechanical strength, which was $57.6 \mathrm{~kg} / \mathrm{cm}^{2}$ as reflowed. This $\mathrm{In} / \mathrm{Ni} / \mathrm{Cu} / \mathrm{Ni} / \mathrm{In}$ multilayer structure is a suitable candidate for high-temperature $\mathrm{Pb}$-free solders.

Key words: $\mathrm{In} / \mathrm{Ni} / \mathrm{Cu} / \mathrm{Ni} / \mathrm{In}$ multilayer, high-temperature $\mathrm{Sn}-\mathrm{Pb}$ solders, intermetallic compounds, mechanical strength

\section{INTRODUCTION}

High-temperature solders possess the following special properties: ${ }^{1}$ a liquidus temperature between $260^{\circ} \mathrm{C}$ and $400^{\circ} \mathrm{C}$, a narrow mushy zone range, a low volume expansion rate in high temperatures, and good mechanical, electrical and conductive performance. Sn-containing 85-97 wt.\% Pb solders have been conventionally used as high-temperature solders. For example, the solidus and liquidus temperatures of the $\mathrm{Sn}-95 \mathrm{~Pb}$ solder are $300^{\circ} \mathrm{C}$ and $314^{\circ} \mathrm{C}$, respectively. Bulk manufacturing soldering needs to be at high temperature between $300^{\circ} \mathrm{C}$ and $350^{\circ} \mathrm{C}$ to maintain good solder-joint stability. For environmental reasons, solders containing $\mathrm{Pb}$ are gradually being replaced by $\mathrm{Pb}$-free solders. Pb-free solders have not entirely replaced high- $\mathrm{Pb}$ solders, and high $\mathrm{Pb}$-containing solders have not yet been prohibited by the restriction of hazardous substances directive (RoHS). That being

(Received September 2, 2014; accepted May 29, 2015;

published online June 13, 2015) said, environmental developments will probably result in the obsolescence of $\mathrm{Sn}-\mathrm{Pb}$ solder at some point in the near future. Thus, discovering new materials or new techniques is an urgent issue. Several candidate alloys, such as Au-20Sn, Bi-Ag, Bi-Sn, Sn-Sb, Al-Zn systems, have been proposed as alternative solders to high-temperature solders. However, none of them can fulfill all the requirements to replace high-Pb content solders. $^{2-4}$ The In/Sn/Metal multilayer structure substrate bonded with $\mathrm{Pb}$-free solders has been successfully adopted in electronic packaging. ${ }^{5-7}$ Yan et al. concluded that the In-48Sn solder bonded strongly with a $\mathrm{Cu}$ substrate, which was proven by fractures occurring at solders instead of at interfacial regions in shear testing. The $\mathrm{In}-\mathrm{Sn} / \mathrm{Cu}$ interfacial reaction revealed the $\mathrm{Cu} / \mathrm{In} / \mathrm{Sn} / \mathrm{Cu}$ joints bonded with the chip at low temperatures formed intermetallic compounds (IMCs), having melting temperature higher than $300^{\circ} \mathrm{C}$. This $\mathrm{Cu} / \mathrm{IMCs} / \mathrm{Cu}$ structure strengthens the bonding of the cap and the base. ${ }^{6}$

This study developed a novel idea to replace hightemperature $\mathrm{Sn}-\mathrm{Pb}$ solders. Because of the high 
electric and thermal conductivities of $\mathrm{Cu}$ and the low eutectic temperature of the In-Sn system, a multilayer structure $(\mathrm{In} / \mathrm{Ni} / \mathrm{Cu} / \mathrm{Ni} / \mathrm{In})$ was constructed through electroplating. The proposed new multi-layer structure-(In/Ni/Cu/Ni/In) has the potential to replace conventional high-temperature $\mathrm{Sn}-\mathrm{Pb}$ solders. The solid-liquid inter-diffusion (SLID) technique was applied as a connection medium. The SLID technique can be used to connect the low-temperature solder and the high-temperature metallic substrate. ${ }^{7,8}$ This $\mathrm{In} / \mathrm{Ni} / \mathrm{Cu} / \mathrm{Ni} / \mathrm{In}$ multi-layer structure is projected to match the qualities of high-temperature $\mathrm{Sn}-\mathrm{Pb}$ solders and could therefore replace them.

\section{EXPERIMENTAL}

Two different sizes of copper were prepared. One thick copper plate (with an area of $1 \mathrm{~cm}^{2}$ and thickness of $1 \mathrm{~mm}$ ) was first electroplated with one layer of Sn with a thickness of $10 \mu \mathrm{m}$. Another thin copper plate (with an area of $0.5 \mathrm{~cm}^{2}$ and thickness of $50 \mu \mathrm{m}$ ) was also electroplated with one layer of $5 \mu \mathrm{m} \mathrm{Ni}$, followed by electroplating one layer of
$10 \mu \mathrm{m}$ In. The commercial electroplating solution (ST-380) was used, and copper plates were electroplated at an electric density of $7.5 \mathrm{~A} / \mathrm{dm}^{2}$ in $2 \mathrm{~min}$, $5.0 \mathrm{~A} / \mathrm{dm}^{2}$ in $2 \mathrm{~min}$ and $6.0 \mathrm{~A} / \mathrm{dm}^{2}$ in $5 \mathrm{~min}$ for the $\mathrm{Sn}, \mathrm{Ni}$ and In layers, respectively. The electroplated copper plates were dipped into rosin mildly activated (RMA) flux and then assembled together as shown in Fig. 1. Then, the assembled solder point samples were aged in a furnace under an air atmosphere without an extra bond force at $200^{\circ} \mathrm{C}$, $240^{\circ} \mathrm{C}$, and $300^{\circ} \mathrm{C}$ for $2 \mathrm{~h}$. These reflowing times were commercial operating parameters suggested by Actron Technology Corporation.

After reflowing, all samples were then aged at $100^{\circ} \mathrm{C}$ for $50-1500 \mathrm{~h}$. After aging, samples were mounted, ground and polished for the IMC examination and identification. Meanwhile, the mechanical shear strength was determined. An electron probe x-ray microanalyzer (EPMA; JEOL JXA-8200; Japan) was used to observe and analyze the IMC composition. The IMC phase was determined by comparison with related phase-diagram databases. A universal testing machine (Shimadzu AI-GS; Japan) was used with a testing speed of $1 \mathrm{~mm} / \mathrm{min}$

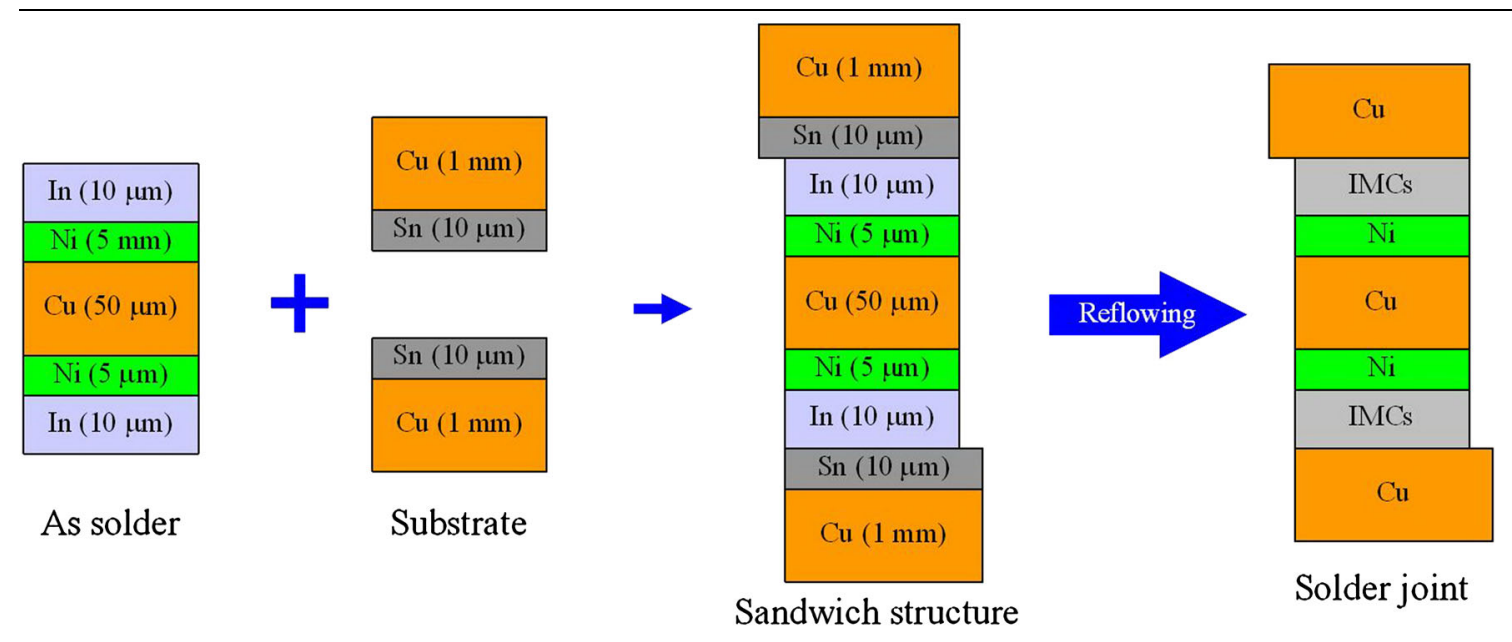

Fig. 1. Schematics of soldering for the $\mathrm{Cu} / \mathrm{Sn} /(\mathrm{In} / \mathrm{Ni} / \mathrm{Cu} / \mathrm{Ni} / \mathrm{In}) / \mathrm{Sn} / \mathrm{Cu}$ sandwich structure.

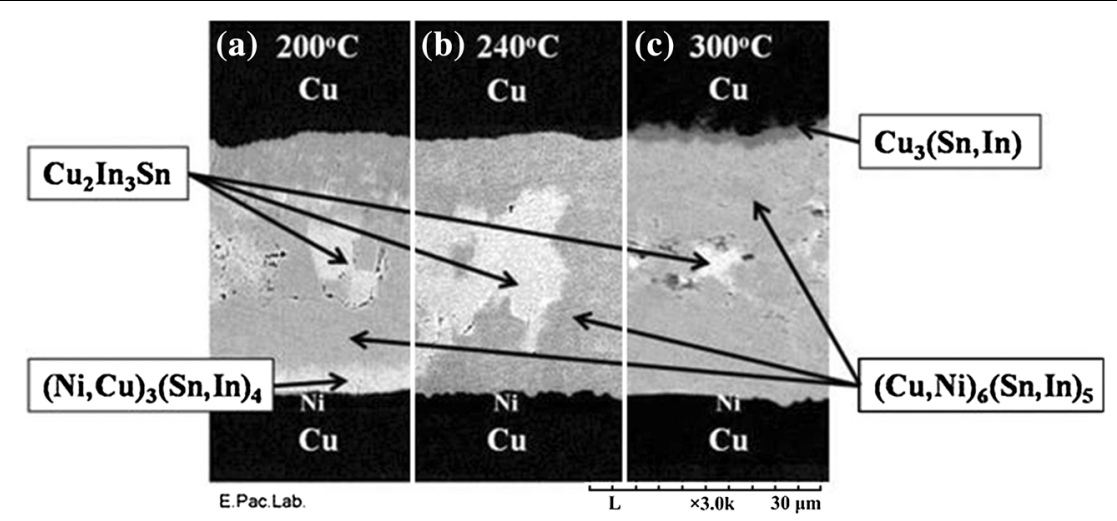

Fig. 2. BEl micrographs of the $\mathrm{Cu} / \mathrm{Sn} /(\mathrm{In} / \mathrm{Ni} / \mathrm{Cu} / \mathrm{Ni} / \mathrm{In}) / \mathrm{Sn} / \mathrm{Cu}$ sandwich couple reflowed at (a) $200^{\circ} \mathrm{C}$, (b) $240^{\circ} \mathrm{C}$ and (c) $300^{\circ} \mathrm{C}$ for $2 \mathrm{~h}$. 
to determine the mechanical shear strength. The test did not stop until the samples were broken.

\section{RESULTS AND DISCUSSION}

Figure 2a shows the BEI (backscattered electron image) micrograph of this $\mathrm{Cu} / \mathrm{Sn} /(\mathrm{In} / \mathrm{Ni} / \mathrm{Cu} / \mathrm{Ni} / \mathrm{In}) /$ $\mathrm{Sn} / \mathrm{Cu}$ sandwich couple reflowed at $200^{\circ} \mathrm{C}$ for $2 \mathrm{~h}$. Three different contrast regions can be observed. The compositions of these three layers were determined by using an EPMA, as shown in Fig. 3, which is the EPMA line-scan compositional profile between the $\mathrm{Ni}$ and $\mathrm{Cu}$ substrates. The gray region has a unique composition of $\mathrm{Cu}-1.5$ at.\% Ni-20.4 at.\% Sn-21.5 at.\% In determined by EPMA analyses. According to the Hume-Rothery rule, ${ }^{9}$ the In and $\mathrm{Sn}$ atoms are interchangeable. The $\mathrm{Cu}-\mathrm{Ni}$ system is an isomorphous system and $\mathrm{Cu}$ and $\mathrm{Ni}$ atoms have mutual solubility in the $\mathrm{Cu}-\mathrm{Ni}$ phase diagram. ${ }^{10}$ Therefore, the In and Sn atoms were combined to calculate the formed IMC composition, and also for the $\mathrm{Cu}$ and $\mathrm{Ni}$ atoms. Thus, the gray region is likely the $(\mathrm{Cu}, \mathrm{Ni})_{6}(\mathrm{Sn}, \mathrm{In})_{5}$ phase. ${ }^{10} \mathrm{In}$ fact, a more detailed analyses and determination for IMC, such as a transmission electron microscopy (TEM) and powder x-ray diffractometer (XRD) analyses should be carried out in the future. However, the EPMA is commonly used to determine the compositions of IMCs and combine the information from the related phase diagrams to identify the IMCs. This method is accepted by most people in the soldering society and the results remain convincing. $3,5,7,11,12$

The data reveal that a considerable amount of In and $\mathrm{Ni}$ atoms are incorporated into the $\mathrm{Sn}$ and $\mathrm{Cu}$ sublattices of the $\mathrm{Cu}_{6} \mathrm{Sn}_{5}$ phase. The micro-island shaped and the light region dispersed among the $(\mathrm{Cu}, \mathrm{Ni})_{6}(\mathrm{Sn}, \mathrm{In})_{5}$ phase with a unique $\mathrm{Cu}-1.0$ at.\% $\mathrm{Ni}-14.6$ at.\% Sn-52.8 at.\% In composition is likely the $\mathrm{Cu}_{2} \mathrm{In}_{3}$ Sn phase. ${ }^{12-14}$ According to Lin's report, the $\mathrm{Cu}_{2} \mathrm{In}_{3} \mathrm{Sn}$ phase was stabilized at $250^{\circ} \mathrm{C} .{ }^{12}$ The composition of the layer structure region close to the $\mathrm{Ni}$ side is $\mathrm{Ni}-11.3$ at.\% Cu-29.5 at.\% Sn-26.8 at.\% In. Koo et al. reported that the layer-shaped $\mathrm{Ni}_{3}(\mathrm{Sn}, \mathrm{In})_{4}$ phase with the Sn-38.4 at.\%Ni-19.1 at.\%In composition was formed in the $\mathrm{In}-48 \mathrm{Sn} / \mathrm{Au} / \mathrm{Ni} / \mathrm{Cu}$ couple. ${ }^{15}$ However, Wang et al. investigated the interfacial reactions between the molten In-49Sn solder and the Ni substrate. They found that the layer-shaped IMC with the Sn-33.1 at.\% Ni-21.4 at.\% In composition was formed at the interface and this layer should be the Ni-In-Sn ternary IMC ${ }^{16}$ In comparison with the Ni-Sn binary phase diagram, ${ }^{10}$ and Koo and Wang's studies, ${ }^{15}, 16$ this continuous layer formed in this study is likely the $(\mathrm{Ni}, \mathrm{Cu})_{3}(\mathrm{Sn}, \mathrm{In})_{4}$ phase, as shown in Fig. 2a.

Figure $2 \mathrm{~b}$ shows the BEI micrograph of this sandwich reflowed at $240^{\circ} \mathrm{C}$ for $2 \mathrm{~h}$. According to EPMA line-scan compositional profile as shown in Fig. 3b, these IMCs formed from the $\mathrm{Cu}$ to $\mathrm{Ni}$ side are the $(\mathrm{Cu}, \mathrm{Ni})_{6}(\mathrm{Sn}, \mathrm{In})_{5}, \quad \mathrm{Cu}_{2} \mathrm{In}_{3} \mathrm{Sn}$ and $(\mathrm{Cu}, \mathrm{Ni})_{6}(\mathrm{Sn}, \mathrm{In})_{5}$ phases, respectively. As the (a) $(\mathrm{Ni}, \mathrm{Cu})_{3}(\mathrm{Sn}, \mathrm{In})_{4}(\mathrm{Cu}, \mathrm{Ni})_{6}(\mathrm{Sn}, \mathrm{In})_{5} \quad \mathrm{Cu}_{2} \mathrm{In}_{3} \mathrm{Sn} \quad(\mathrm{Cu}, \mathrm{Ni})_{6}(\mathrm{Sn}, \mathrm{In})_{5}$

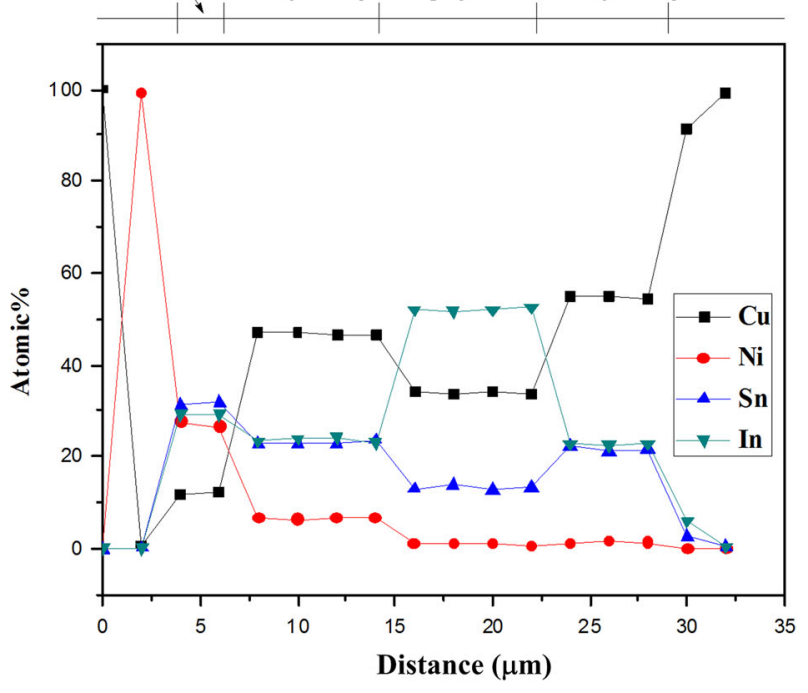

(b)
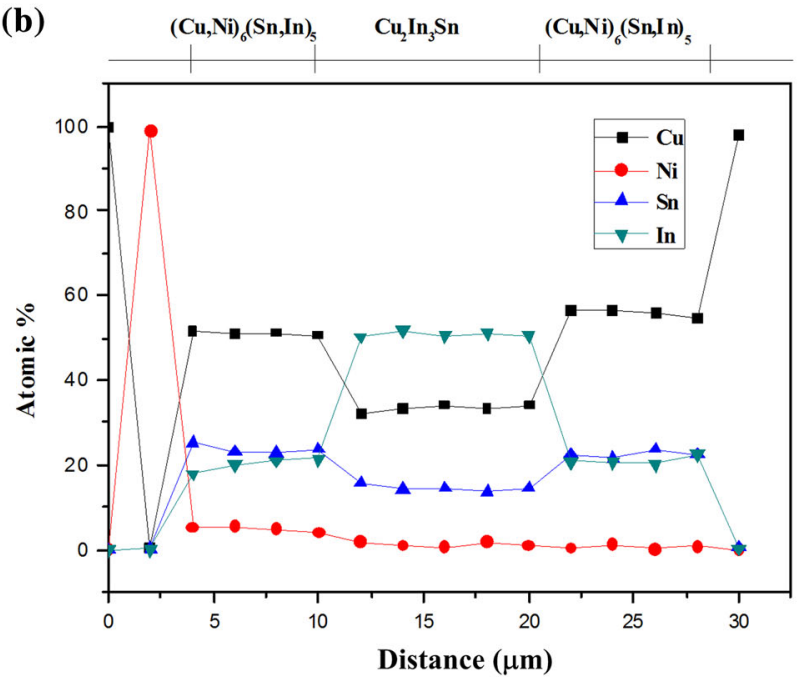

(c) $\quad(\mathrm{Cu}, \mathrm{Ni})_{6}(\mathrm{Sn}, \mathrm{In})_{5} \quad \mathrm{Cu}_{2} \mathrm{In}_{3} \mathrm{Sn} \quad(\mathrm{Cu}, \mathrm{Ni})_{6}(\mathrm{Sn}, \mathrm{In})_{5} \quad \mathrm{Cu}_{3}(\mathrm{Sn}, \mathrm{In})$

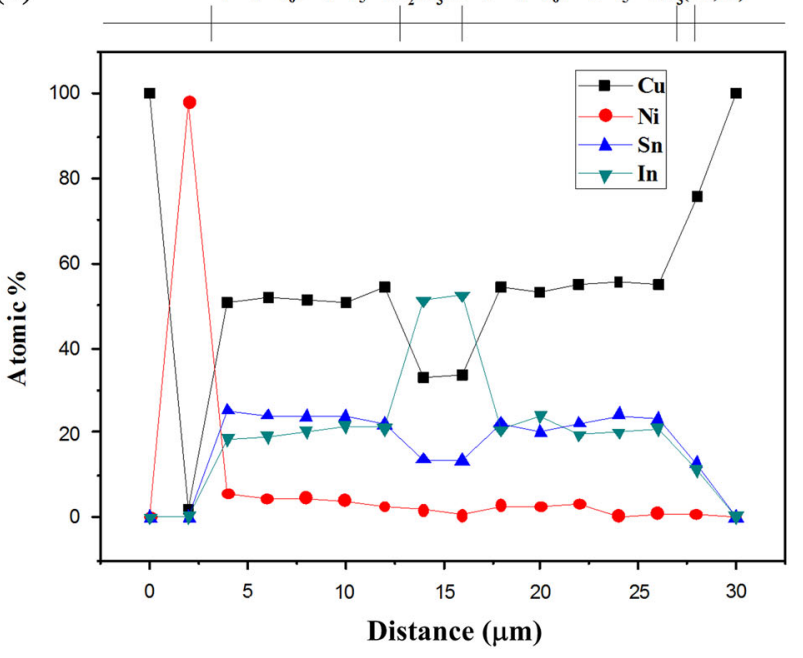

Fig. 3. EPMA line-scan compositional profile of the $\mathrm{Cu} / \mathrm{Sn} /(\mathrm{In} / \mathrm{Ni} / \mathrm{Cu} /$ $\mathrm{Ni} / \mathrm{In}$ )/Sn/Cu sandwich couple reflowed at (a) $200^{\circ} \mathrm{C}$, (b) $240^{\circ} \mathrm{C}$ and (c) $300^{\circ} \mathrm{C}$ for $2 \mathrm{~h}$. 


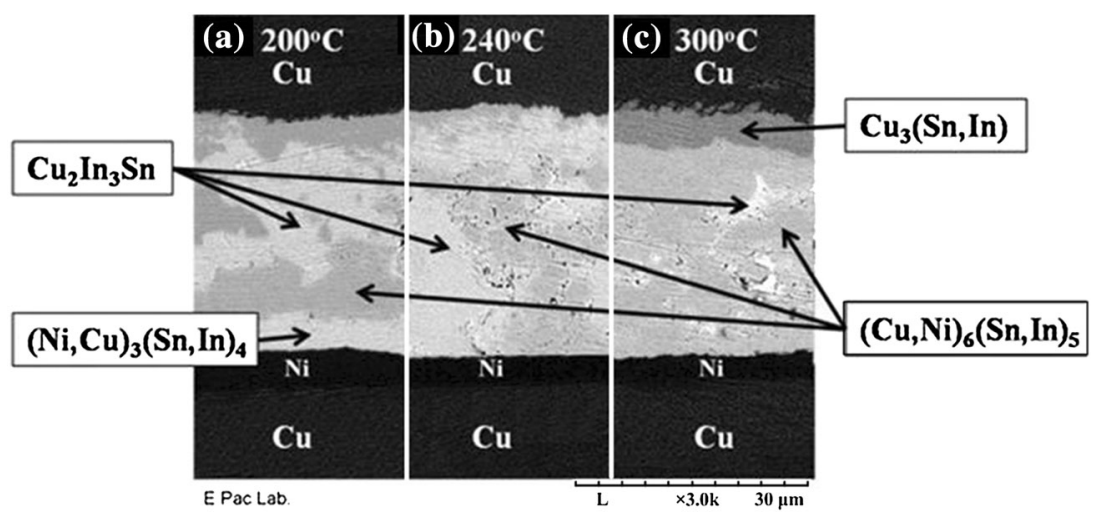

Fig. 4. BEl micrographs of the $\mathrm{Cu} / \mathrm{Sn} /(\mathrm{In} / \mathrm{Ni} / \mathrm{Cu} / \mathrm{Ni} / \mathrm{In}) / \mathrm{Sn} / \mathrm{Cu}$ sandwich couple reflowed at (a) $200^{\circ} \mathrm{C}$, (b) $240^{\circ} \mathrm{C}$ and (c) $300^{\circ} \mathrm{C}$ for $2 \mathrm{~h}$ and aging at $100^{\circ} \mathrm{C}$ for $1500 \mathrm{~h}$.

Table I. Evolution of IMCs ( $\mathrm{Cu}$ side to $\mathrm{Ni}$ side) in the $\mathrm{Cu} / \mathrm{Sn} / \mathrm{In} / \mathrm{Ni} / \mathrm{Cu} / \mathrm{Ni} / \mathrm{InSn} / \mathrm{Cu}$ couple reflowed at $200-300^{\circ} \mathrm{C}$ for $2 \mathrm{~h}$ and then aged at $100^{\circ} \mathrm{C}$ for $50-1000 \mathrm{~h}$

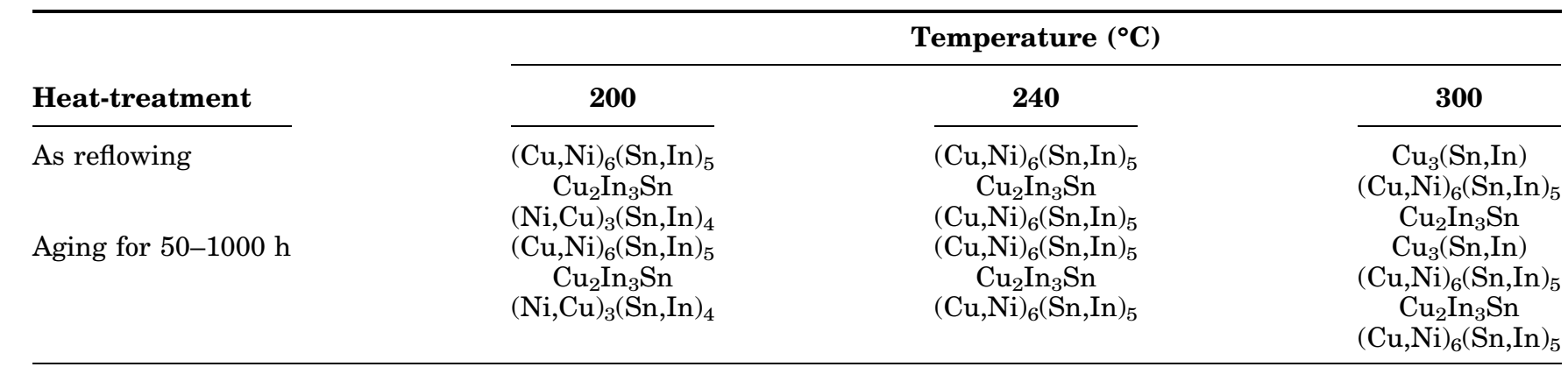

reflowing temperature was increased to $240^{\circ} \mathrm{C}$, the $\mathrm{Sn}$ layer completely melted and $\mathrm{Cu}$ atoms could more easily dissolve into the molten solder then diffuse toward the $\mathrm{Ni}$ side. The local $\mathrm{Cu}$ concentration on the $\mathrm{Ni}$ side would become greater. In this condition, the $(\mathrm{Ni}, \mathrm{Cu})_{3}(\mathrm{Sn}, \mathrm{In})_{4}$ phase would become unstable and the phase equilibrium condition changed into the two-phase region composed of $\left(\mathrm{L}+\mathrm{Cu}_{6} \mathrm{Sn}_{5}\right)$. That is why the $(\mathrm{Cu}, \mathrm{Ni})_{6}(\mathrm{Sn}, \mathrm{In})_{5}$ phase instead of the $(\mathrm{Ni}, \mathrm{Cu})_{3}(\mathrm{Sn}, \mathrm{In})_{4}$ phase was formed at the $\mathrm{Ni}$ side. This result was similar to that in Chen's study. ${ }^{17}$ When the $\mathrm{Cu}$ concentration became high enough, the phase equilibrium condition would transfer from $\left(\mathrm{L}+\mathrm{Ni}_{3} \mathrm{Sn}_{4}\right)$ to $\left(\mathrm{L}+\mathrm{Cu}_{6}\right.$ $\mathrm{Sn}_{5}$ ) in the Cu-Ni-Sn ternary system. ${ }^{18}$ When the reflowing temperature was increased to $300^{\circ} \mathrm{C}$, the $\mathrm{Cu}_{3}(\mathrm{Sn}, \mathrm{In}), \mathrm{Cu}_{2} \mathrm{In}_{3} \mathrm{Sn}$, and $(\mathrm{Cu}, \mathrm{Ni})_{6}(\mathrm{Sn}, \mathrm{In})_{5}$ phase were found at the interface, as shown in Figs. 2c and 3c. This result was similar to that in the $\mathrm{Cu} / \mathrm{Sn} /$ $(\mathrm{In} / \mathrm{Ni} / \mathrm{Cu} / \mathrm{Ni} / \mathrm{In}) / \mathrm{Sn} / \mathrm{Cu}$ couple reflowed at $240^{\circ} \mathrm{C}$. Meanwhile, the $\mathrm{Cu}_{3}(\mathrm{Sn}, \mathrm{In})$ phase close to the $\mathrm{Cu}$ side was observed in this sandwich couple. This result was similar to that in Chuang's study. ${ }^{11}$ They reported that the $\mathrm{Cu}_{3}(\mathrm{Sn}, \mathrm{In})$ phase was formed when the reaction temperature was higher than $300^{\circ} \mathrm{C}$. After reflowing, each sandwich couple was then aged at $100^{\circ} \mathrm{C}$ for $50 \mathrm{~h}$ to $1500 \mathrm{~h}$. Figure 4 shows the surface morphologies of these three sandwich couples reflowed at (a) $200^{\circ} \mathrm{C}$, (b) $240^{\circ} \mathrm{C}$ and (c) $300^{\circ} \mathrm{C}$ then aged at $100^{\circ} \mathrm{C}$ for $1500 \mathrm{~h}$. These results indicate that the increase in aging time would not change the types of IMC formation at the interface, but all IMC thicknesses were increased with the increase of aging time.

The evolution of all IMC formation at the interface in the $\mathrm{Cu} / \mathrm{Sn} /(\mathrm{In} / \mathrm{Ni} / \mathrm{Cu} / \mathrm{Ni} / \mathrm{In}) / \mathrm{Sn} / \mathrm{Cu}$ sandwich couple as reflowed at $200-300^{\circ} \mathrm{C}$ and aged at $100^{\circ} \mathrm{C}$ for various times is listed in Table I. The results indicate that the aged time effect is not significant enough to influence the interfacial reaction but IMC formation is sensitive to the reflowing temperature between the $\mathrm{In} / \mathrm{Ni} / \mathrm{Cu} / \mathrm{Ni} / \mathrm{In}$ multilayer and $\mathrm{Cu}-\mathrm{Sn}$ substrate. When the reflowing temperature was raised to $300^{\circ} \mathrm{C}$, a new IMC, the $\mathrm{Cu}_{3}(\mathrm{Sn}, \mathrm{In})$ phase, was formed at the $\mathrm{Cu}$ side and its thickness was increased as the aging time was increased. Meanwhile, the $(\mathrm{Ni}, \mathrm{Cu})_{3}(\mathrm{Sn}, \mathrm{In})_{4}$ phase disappeared when the reflowing temperature was higher than $200^{\circ} \mathrm{C}$.

Figure 5 shows the BEI images of the fracture surface after shear tests for the $\mathrm{Cu} / \mathrm{Sn} /(\mathrm{In} / \mathrm{Ni} / \mathrm{Cu} / \mathrm{Ni} /$ $\mathrm{In}) / \mathrm{Sn} / \mathrm{Cu}$ sandwich couples reflowed at (a) $200^{\circ} \mathrm{C}$, (b) $240^{\circ} \mathrm{C}$ and (c) $300^{\circ} \mathrm{C}$ for $2 \mathrm{~h}$. As shown in Fig. $5 \mathrm{a}$, only the $(\mathrm{Ni}, \mathrm{Cu})_{3}(\mathrm{Sn}, \mathrm{In})_{4}$ phase and many dimples are observed at the fracture surface in the sandwich couple reflowed at $200^{\circ} \mathrm{C}$. When the reflowing temperature was increased to $300^{\circ} \mathrm{C}$, a smooth 

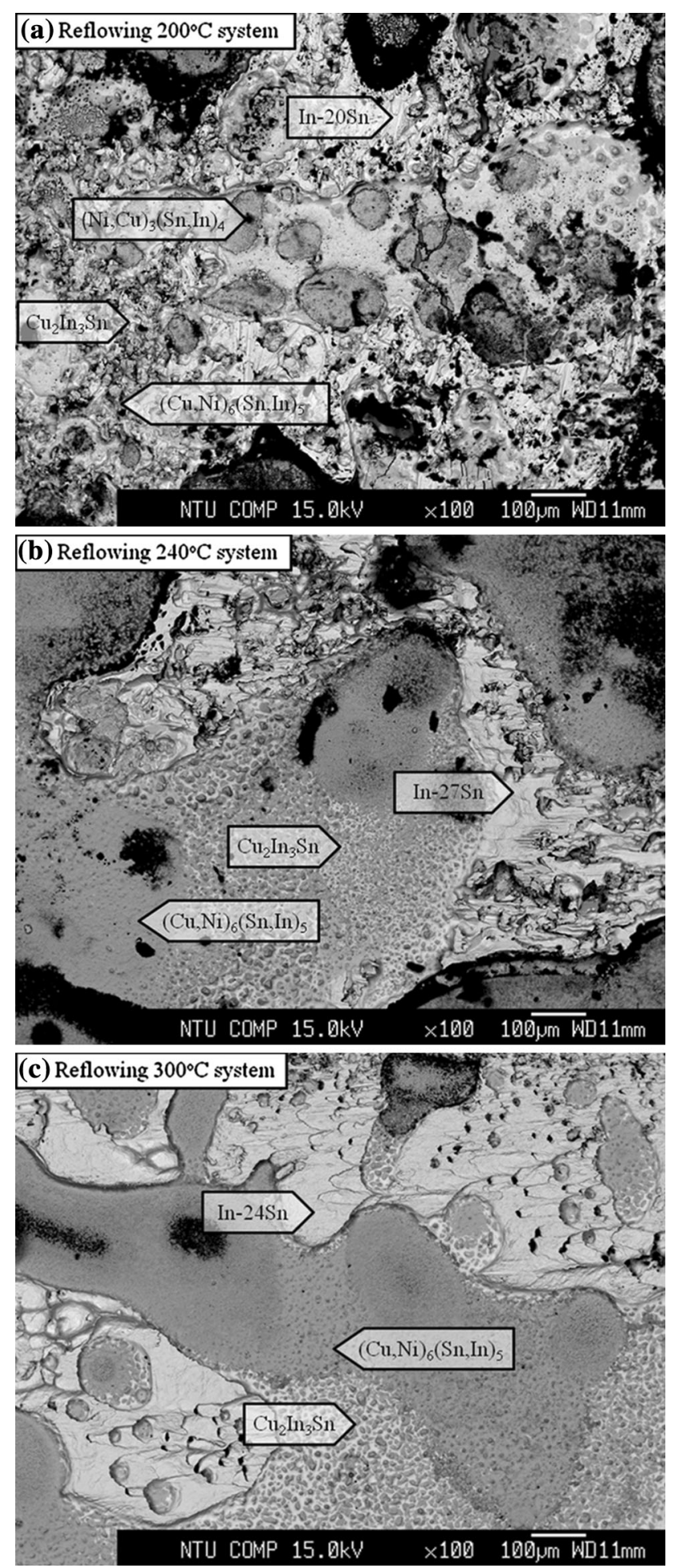

Fig. 5. BEI micrographs of the fracture surface after shear tests for the $\mathrm{Cu} / \mathrm{Sn} /(\mathrm{In} / \mathrm{Ni} / \mathrm{Cu} / \mathrm{Ni} / \mathrm{In}) / \mathrm{Sn} / \mathrm{Cu}$ sandwich couple reflowed at (a) $200^{\circ} \mathrm{C}$, (b) $240^{\circ} \mathrm{C}$ and (c) $300^{\circ} \mathrm{C}$ for $2 \mathrm{~h}$.

fractured plane along the fracture surface was observed (Fig. 5c). The fracture type changed from a brittle fracture into a ductile fracture contributed by the thicker $(\mathrm{Cu}, \mathrm{Ni})_{6}(\mathrm{Sn}, \mathrm{In})_{5}$ phase formed at the

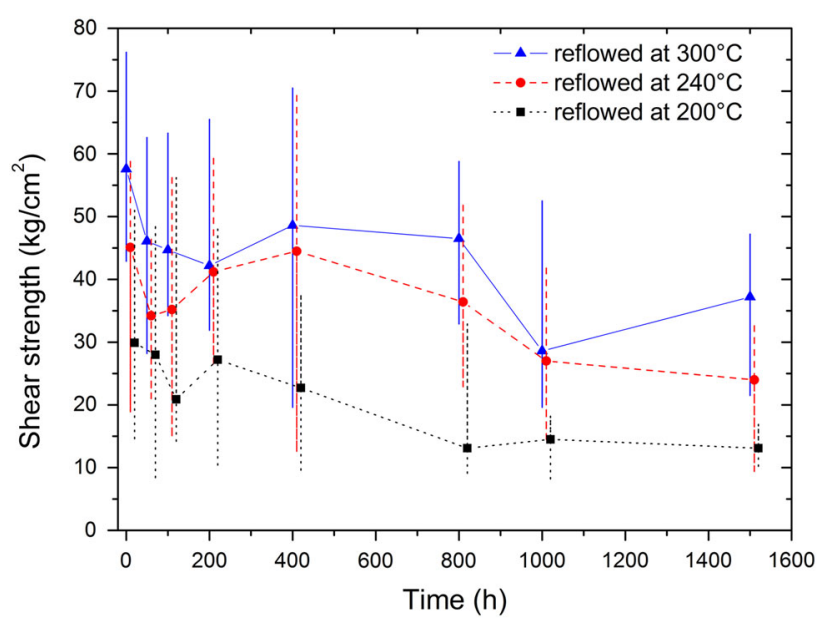

Fig. 6. Shear strength of the solder joint in the $\mathrm{Cu} / \mathrm{Sn} /(\mathrm{In} / \mathrm{Ni} / \mathrm{Cu} / \mathrm{Ni} /$ $\mathrm{In} / \mathrm{Sn} / \mathrm{Cu}$ sandwich couple under different reflow conditions for $2 \mathrm{~h}$ at different temperatures $\left(200^{\circ} \mathrm{C} ; 240^{\circ} \mathrm{C} ; \boldsymbol{\Delta} 300^{\circ} \mathrm{C}\right)$ and then aged at $100^{\circ} \mathrm{C}$ for $50-1000 \mathrm{~h}$.

interface. Some In-rich phases with small areas are observed in the matrix in these three samples in Fig. 5. Both Sn and In have a high ductility, thus Sn or In atoms might be spread over the fracture surface after the shear testing. These In-rich phases were not formed at the interface during reflowing.

Figure 6 illustrates the average shear strength of the 24 solder joints in these sandwich couples reflowed at various temperatures for $2 \mathrm{~h}$ and then aged at $100^{\circ} \mathrm{C}$ for $50-1500 \mathrm{~h}$. The shear strength tendency in Fig. 6 decreased when the reflowing temperatures were decreased and aging time increased. Based on Koo's report, the $\mathrm{Ni}_{3}(\mathrm{Sn}, \mathrm{In})_{4}$ phase formation would reduce the solder-joint shear strength. ${ }^{16}$ The $\mathrm{Ni}_{3}(\mathrm{Sn}, \mathrm{In})_{4}$ phase was only formed when the reflowing temperature was at $200^{\circ} \mathrm{C}$. This might be the reason for the deterioration in the shear stress. The lowest shear strength values were always found on the solder joint reflowed at $200^{\circ} \mathrm{C}$.

Due to the lesser amount of the $\mathrm{Cu}_{2} \mathrm{In}_{3} \mathrm{Sn}$ phase in the sandwich couple reflowed at $300^{\circ} \mathrm{C}$, the shear strength value on the solder joints reflowed at $300^{\circ} \mathrm{C}$ is higher than that reflowed at $200^{\circ} \mathrm{C}$ or $240^{\circ} \mathrm{C}$. The $\mathrm{Ni}_{3}(\mathrm{Sn}, \mathrm{In})_{4}$ and $\mathrm{Cu}_{2} \mathrm{In}_{3} \mathrm{Sn}$ IMCs produce poor solder-joint mechanical strength. The shear strength values of the solder joints in this sandwich couple as reflowed at $300^{\circ} \mathrm{C}$ and then annealed at $100^{\circ} \mathrm{C}$ for $1500 \mathrm{~h}$ are $57.6 \mathrm{~kg} / \mathrm{cm}^{2}$ and $37.2 \mathrm{~kg} / \mathrm{cm}^{2}$, respectively. These results can be compared with the interfacial tensile strength value of $52 \mathrm{~kg} / \mathrm{cm}^{2}$ from Yan's report, ${ }^{6}$ who tested the $\mathrm{Cu} / \mathrm{In} / \mathrm{Sn} / \mathrm{Cu}$ structure bonded at $180^{\circ} \mathrm{C}$ for $20 \mathrm{~min}$. The result reveals that replacing high-temperature $\mathrm{Sn}-\mathrm{Pb}$ solders with the $(\mathrm{In} / \mathrm{Ni} / \mathrm{Cu} / \mathrm{Ni} / \mathrm{In})$ multilayer solder would be useful in the electronics packaging industry. 


\section{CONCLUSIONS}

The $(\mathrm{Ni}, \mathrm{Cu})_{3}(\mathrm{Sn}, \mathrm{In})_{4}, \mathrm{Cu}_{2} \mathrm{In}_{3} \mathrm{Sn}$ and $(\mathrm{Cu}, \mathrm{Ni})_{6}$ $(\mathrm{Sn}, \mathrm{In})_{5}$ phases were formed when the reflowing temperature was at $200^{\circ} \mathrm{C}$. When the reflowing temperature was increased to $240^{\circ} \mathrm{C}$, the $(\mathrm{Cu}, \mathrm{Ni})_{6}$ $(\mathrm{Sn}, \mathrm{In})_{5} / \mathrm{Cu}_{2} \mathrm{In}_{3} \mathrm{Sn} /(\mathrm{Cu}, \mathrm{Ni})_{6}(\mathrm{Sn}, \mathrm{In})_{5}$ structure was observed between the $\mathrm{Cu}$ and $\mathrm{Ni}$ side. When the sandwich couple was reflowed at $300^{\circ} \mathrm{C}$, the $\mathrm{Cu}_{3}(\mathrm{Sn}$, $\mathrm{In}),(\mathrm{Cu}, \mathrm{Ni})_{6}(\mathrm{Sn}, \mathrm{In})_{5}, \mathrm{Cu}_{2} \mathrm{In}_{3} \mathrm{Sn}$, and $(\mathrm{Cu}, \mathrm{Ni})_{6}(\mathrm{Sn}$, $\mathrm{In})_{5}$ phases were observed from the $\mathrm{Cu}$ to the $\mathrm{Ni}$ side. These results indicate that the reflowing temperature has a significant influence on the interfacial reaction between the $(\mathrm{In} / \mathrm{Ni} / \mathrm{Cu} / \mathrm{Ni} / \mathrm{In})$ multilayer and the $\mathrm{Sn} / \mathrm{Cu}$ substrate. The best solder-joint shear strength was obtained in the $\mathrm{Cu} / \mathrm{Sn} /$ $(\mathrm{In} / \mathrm{Ni} / \mathrm{Cu} / \mathrm{Ni} / \mathrm{In}) / \mathrm{Sn} / \mathrm{Cu}$ sandwich couple reflowed at $300^{\circ} \mathrm{C}$. These values were higher than the literature data. This $(\mathrm{In} / \mathrm{Ni} / \mathrm{Cu} / \mathrm{Ni} / \mathrm{In})$ multilayer might be suitable for use as a high-temperature $\mathrm{Pb}$-free solder in the electronics packaging industry.

\section{ACKNOWLEDGEMENTS}

The authors acknowledge financial support from the Ministry of Education (MoE) Top University Projects. The author is also grateful for the help from Mr. S.C. Laiw who works at the National Taiwan University of Science and Technology for SEM-EDS operation and Mr. C.Y. Kao who works at the National Taiwan University for carrying out the EPMA analysis.

\section{REFERENCES}

1. K. Suganuma, S.J. Kim, and K.S. Kim, JOM 61, 64 (2009).

2. V. Chidambaram, J. Hattel, and J. Hald, Microelectron. Eng. 88, 981 (2011)

3. M. Nahavandi, M.A. Azmah Hanim, Z.N. Ismarrubie, A. Hajalilou, R. Rohaizuan, and M.Z.S. Fadzli, J. Electron. Mater. 43, 579 (2014).

4. Y. Du, C. Li, B. Huang, M. Tang, and C. Du, Solder. Surf. Mt. Technol. 27, 7 (2015).

5. S.W. Chen, S.K. Lin and C.F Yang. J. Electron. Mater. 35, 72 (2006).

6. L. Yan, C. Lee, D. Yu, W.K. Choi, A. Yu, S.U. Yoon, and J.H. Lao, Proceeding 58th Electronic Components and Technology Conference, p. 1844 (2008).

7. Y.W. Yen, W.K. Liou, H.Y. Wei, and C. Lee, J. Electron. Mater. 38, 93 (2009).

8. S. Bader, W. Gust, and H. Hieber, Acta Metall. Mater. 43, 329 (1995).

9. W. Hume-Rothery, J. Inst. Met. 35, 295 (1926).

10. T.B. Massalski, Binary Alloy Phase Diagrams-CD-ROM, Materials Park (OH: ASM International, 1996).

11. T.H. Chuang, C.L. Yu, S.Y. Chang, and S.S. Wang, J. Electron. Mater. 31, 640 (2002).

12. S.K. Lin, T.Y. Chung, S.W. Chen, and C.H. Chang, J. Mater. Res. 24, 2628 (2009).

13. A.D. Roming, F.G. Yost, and P.F. Hiava, Proc. Microbeam Anal. 1984, ed. A.D. Romig, Jr. and J.I. Goldstein (San Francisco Press, San Francisco, 1984), p. 87.

14. J.L. Freer and J.W. Morris, J. Electron. Mater. 21, 647 (1992).

15. J.M. Koo and S.B. Jung, J. Electron. Mater. 34, 1565 (2005).

16. S.S. Wang, Y.H. Tseng, and T.H. Chuang, J. Electron. Mater. 35, 165 (2006).

17. W.T. Chen, C.E. Ho, and C.R. Kao, J. Mater. Res. 17, 263 (2002).

18. C.H. Ho, Y.W. Lin, S.C. Yang, C.R. Kao, and D.S. Jian, J. Electron. Mater. 35, 1017 (2006). 